license

\title{
Implementasi Pengembangan Wisata Kampung Keramat di Kota Malang
}

\author{
Muhammad Fahmil Islami ${ }^{1}$, Khrisno Hadi ${ }^{2}$ \\ islamyfahmy@gmail.com; khrisno_hadi@yahoo.co.id \\ ${ }^{1}$ Program Studi Ilmu Pemerintahan, Universitas Muhammadiyah Malang \\ ${ }^{2}$ Program Studi Ilmu Pemerintahan, Universitas Muhammadiyah Malang \\ DOI: $10.22219 /$ sospol.v7i2.11307
}

\begin{abstract}
This article aims to see how the collaboration between the government, the private sector and the community in building a relationship and synergy in an effort to carry out the construction of the Kampung Keramat in Malang City. The concept used is Collaborative Governance as an analytical tool to describe the topics raised. Then the method used by the author is descriptive qualitative research, the data sources used are primary and secondary, then the data collection techniques used are interviews, observation and documentation. The research subjects used purposive sampling. As a result, there are two program activities, namely the first physical development such as museums, tomb gates, pergolas, parks, public road facilities and UKM center kiosks, painting murals and making branding boards and location plans. Then the non-physical is Product Marketing Training through the web. In terms of monitoring and evaluation of the Kampung Keramat development program, from the technical side and the performance of the parties, there were no obstacles, and development in the RT $07100 \%$ realized.
\end{abstract}

\begin{abstract}
Abstrak
Artikel ini bertujuan untuk melihat bagaimana kolaborasi antara antara pemerintah, swasta maupun masyarakat dalam membangun sebuah relasi dan sinergitas dalam upaya melaksanakan pembangunan Kampung Keramat di Kota Malang. Konsep yang digunakan yaitu Collaborative Governance sebagai pisau analisa untuk mendeskripsikan topik yang diangkat. Kemudian metode yang digunakan oleh penulis adalah menggunakan penelitian deskriptif kualitatif, Sumber data yang digunakan adalah primer dan sekunder, kemudian teknik pengumpulan data yang digunakan adalah wawancara, observasi beserta dokumentasi. Subyek penelitian yang digunakan purposive sampling. Sebagai hasilnya, terdapat dua progam kegiatan yakni pertama pembangunan fisik contohnya museum, gapura makam, pergola, taman, fasilitas jalan umum dan kios sentra UKM, pengecatan gambar mural dan pembuatan papan branding dan denah lokasi. Kemudian yang non fisik adalah Pelatihan Pemasaran Produk melalui web. Secara monitoring dan evaluasi pada program pembangunan Kampung Keramat adalah dari sisi teknis dan kinerja para pihak tidak ditemukan kendala, dan pembangunan di RT 07 100\% teralisasi.
\end{abstract}

\author{
Keywords \\ Kampung Keramat, Kolaborasi, \\ Pengembangan Wisata, Tata Kelola
}

\section{Article History}

Received February 18, 2020

Revised November 10, 2021

Accepted November 11, 2021

Published November 16, 2021

\section{Corresponding Author}

Muhammad Fahmil Islami. Kampus III UMM, Jl. Raya Tlogomas, No 246, Kec. Lowokwaru, Kota Malang. 65144.

\section{Pendahuluan}

Kampung Keramat yang terletak di Kelurahan Kasin, Kecamatan Klojen, Kota Malang merupakan kampung yang memiliki ciri khas tersendiri dibandingkan dengan kampung inovatif lainnya di Kota Malang. Pengistilahan Kampung Keramat yang digagas oleh warga Kelurahan Kasin memiliki alasan tersendiri, bahwa kampung tersebut terletak di dekat Tempat Pemakaman Umum (TPU). Konsep yang dibangun dari Kampung Keramat ini memiliki dua konsep, yaitu 
license

konsep edukasi dan wisata religi. Kelurahan Kasin merupakan salah satu kelurahan yang mana sebagian besar warganya bermata pencaharian sebagai tukang penjual ban dan pengrajin manikmanik. Warga Kelurahan Kasin ingin mencoba menggabungkan dua mata pencaharian tersebut sebagai bahan untuk inovasi kampung mereka (Primavera, 2017). Hal inilah yang menjadikan warga Kelurahan Kasin bertekad untuk mengubah kampung mereka menjadi kampung yang berbasis wisata dan edukasi.

Adapun pengembangan destinasi wisata yang ada di Kota Malang sudah diatur dalam Peraturan Walikota Malang Nomor 34 Tahun 2014 tentang Rencana Induk Pengembangan Pariwisata Daerah, menimbang bahwa Kota Malang memiliki potensi wilayah yang dapat dibina sebagai wilayah pengembangan destinasi wisata dalam menunjang pembangunan daerah. Pada dasarnya pengembangan wisata ini tidak dimaksudkan dalam hal menambah keuntungan finasial saja, akan tetapi juga memiliki maksud dalam mengutamakan dari segi keagamaan, pendidikan, budaya, lingkungan hidup, dan mengutamakan ketentraman dan ketertiban serta kenyamanan. Peraturan yang menjadi dasar pembangunan destinasi wisata ini tidak hanya bermanfaat bagi pemerintah saja, namun juga berfungsi untuk memberdayakan masyarakat sekitar agar dapat mengembangkan potensinya. Adanya wisata Kampung Keramat tersebut diharapkan dapat menjadi peluang bagi warganya untuk mengembangkan potensi ekonomi kreatif yang dapat menghidupi warga sekitar.

Fokus permasalahan yang dibahas dalam penelitian ini adalah terletak pada tolak ukur kerjasama yang dibangun. Artinya, kerjasama yang dibangun oleh beberapa aktor yang terlibat pada saat pembangunan Kampung Keramat, perlu kiranya penulis untuk mengetahui sejauh mana tanggung jawab atau tugas yang sudah mereka laksanakan. Hal ini diperlukan agar penulis dapat mengetahui progres kerjasama yang sudah mereka laksanakan sesuai dengan tugas dan kemampuan masing-masing aktor. Sedangkan kerjasama pembangunan kampung ini terbentuk karena adanya Lomba Kampung Tematik Se-Malang Raya yang diadakan oleh Pemerintah Kota Malang Tahun 2017 (Sakti, 2017). Kampung Keramat memenangkan pendanaan dari acara tersebut, yang digunakan untuk pengembangan kampung tersebut dengan melibatkan kerjasama antara pihak kelurahan, masyarakat yang tergabung dalam Pokdarwis, dan swasta yang terdiri dari IAI (Ikatan Arsitektur Indonesia), UTERO Malang, MCF (Malang Creative Fusion), dan Perusahaan cat PT. Propan Malang (Hidayatullah, 2018).

Terdapat beberapa penelitian serupa yang membahas tentang kampung kreatif yang dalam proses pembangunannya melibatkan kerjasama multi-aktor. Seperti yang diungkapkan oleh Jordan Aria Adibrata dalam tulisannya, yakni mengenai pembangunan Kampung Jodipan di Kota Malang yang merupakan hasil inisiasi dari kelompok pemuda yang bekerjasama dengan perusahaan swasta dan pemerintah daerah dalam pembangunannya (Adibrata et al., 2020). Daerah yang awalnya merupakan slum area disulap melalui inisiasi kerjasama para aktor tersebut sehingga menjadi kampung kreatif yang dapat menghasilkan pendapatan sekaligus memberdayakan para warganya. Pembangunan dan pengembangan kampung tersebut selaras dengan nilai-nilai Sustainable Development Goals (SDGs) poin ke 11 dengan mengubah slum area menjadi wilayah yang layak huni, produktif, serta berkelanjutan. 
Selain itu, artikel yang ditulis oleh Agnes Anggi Hasian Silaban mengambil objek Kampung Wisata Kreatif Dago Pojok di Kota Bandung juga merupakan hasil dari kerjasama antara masyarakat, pemerintah, dan aktor NGO (Silaban \& Bhaskara, 2020). Kampung yang memiliki potensi di bidang kesenian tersebut dimanfaatkan dan dikembangkan lebih jauh untuk mewujudkan misi Bandung Creative City (BCC). Puncaknya, kampung tersebut sukses sebagai destinasi bagi berbagai acara mulai dari Konferensi Asia Afrika di tahun 2014 hingga Festival Anti Korupsi Sedunia oleh KPK di tahun 2015. Namun kampung tersebut kembali terbengkalai dikarenakan banyak warganya telah berpindah tempat sehingga kepengurusannya tidak berjalan dengan optimal. Kedua penelitian tersebut selaras dengan topik yang diangkat penulis yakni mengenai relasi multi-aktor dalam mengembangkan kampung sebagai potensi ekonomi dan wisata yang dapat memberdayakan warganya.

Untuk memahami implementasi pengembangan Kampung Keramat dan relasinya dengan berbagai aktor dibaliknya, penulis menggunakan konsep Collaborative Governance sebagai pisau analisa. Kolaborasi antara berbagai aktor dalam pengembangan pariwisata merupakan suatu alternatif untuk mempermudah proses berjalannya pengembangan pariwisata. Terdapat beberapa tahapan mengenai konsep kolaborasi tersebut dalam hal pengembangan pariwisata, yakni; membangun visi bersama, partisipasi, jejaring, dan kemitraan (Wanna, 2008). Sehingga penggunaan konsep ini menjadi penting untuk melihat arus implementasi kerjasama tersebut dari hulu hingga ke hilir.

Oleh karena itu menjadi menarik untuk mengangkat Kampung Keramat di Kota Malang menjadi objek penelitian karena pembangunan kampung tersebut masih dalam tahap proses. Maka penulis tertarik memetakan siapa saja aktor yang terlibat dalam pembangunan kampung tersebut secara lebih detail. Selain itu, penulis juga ingin melihat pola kolaborasi antara pemerintah, swasta maupun masyarakat dalam membangun sebuah relasi dalam upaya melaksanakan pembangunan Kampung Keramat di Kelurahan Kasin. Disamping itu hasil dari implementasi kerjasama tersebut juga menjadi aspek yang perlu dilihat, selesainya pembangunan kampung tersebut juga menarik untuk diketahui agar dapat melihat signifikansi dampak dari pembangunan kampung tersebut bagi masyarakat sekitar.

\section{Metode}

Jenis penelitian yang digunakan dalam penelitian ini adalah deskriptif kualitatif yang artinya menggambarkan fenomena yang ada sesuai kondisi di lapangan (Sugiyono, 2016). Dalam subyek penelitian penulis menggunakan teknik purposive sampling yang berarti sebuah teknik mengenai pengambilan data sampel dengan berbagai pertimbangan tertentu (Sugiyono, 2016). Sumber data yang digunakan adalah primer dan sekunder artinya data berdasarkan wawancara, jurnal, buku, artikel, internet dan rekaman. Teknik pengumpulan data yang digunakan adalah observasi, wawancara dan dokumentasi. Teknik analisa data yang digunakan adalah model analisis data Milles dan Huberman model kualitatif yang artinya data tersebut diperoleh berdasarkan dari hasil observasi, wawancara, dokumentasi dan lain-lain (Milles \& Huberman, 1992). 
license

\section{Hasil dan Pembahasan}

\section{Awal Mula Terbentuknya Kerjasama Pembangunan Kampung Keramat}

Perlu kita ketahui bahwasanya awal mula terbentuknya kerjasama pengembangan Kampung Keramat di Kelurahan Kasin berawal dari adanya lomba Kampung tematik yang diadakan oleh pemerintah Kota Malang pada tahun 2017 melalui Badan Perencanaan dan Pembangunan Daerah Kota Malang (Bappeda) sebagai institusi penyelenggara lomba tersebut. Pada saat itu berdasarkan hasil undian tersebut Kampung Keramat mendapatkan pendamping dari IAI (Ikatan Arsitektur Indonesia). Pendamping ini mendapatkan mandat dari pemerintah kota Malang untuk bertugas dalam memberikan pendampingan kepada para peserta lomba dengan cara membantu dalam membuatkan DED atau perencanaan mengenai desain kampung kampung yang ingin dibangun. Sehingga dari sisi perencanaan desain masyarakat tidak merasa kesulitan dalam membuatnya karena sudah ada pihak pendamping yang membantu dalam pembuatan DED atau perencanaan desain kampung mereka tersebut.(Azhari, 2019)

Kemudian Kabar baiknya Kampung Keramat mendapatkan juara 3 dalam lomba tersebut dan mendapatkan hadiah uang senilai satu milyar rupiah. Sehingga uang tersebut dipergunakan untuk keberlanjutan pembangunan Kampung Keramat. Dari sinilah pihak Kelurahan Kasin serta masyarakat berkeinginan untuk membuka peluang kerjasama pihak swasta dalam mendukung pengembangan Kampung Keramat. adapun pihak-pihak yang dilibatkan dalam kerjasama ini adalah Pihak IAI (Ikatan Arsitektur Indonesia) sebagai pihak pendamping Kampung Keramat dalam membuatkan DED Perencanaan Pengembangan Kampung Keramat, UTERO Malang, MCF (Malang Creative Fusion), dan Perusahaan Cat PT. Propan Malang. pihak-pihak swasta inilah yang menjadi mitra dalam pengembangan Kampung Keramat.

\section{Pemetaan Para Pihak Yang Terlibat dalam Kerjasama}

Berdasarkan penjelasan yang disampaikan oleh Ibu Yuyun Sulistyowati selaku Lurah di Kelurahan Kasin dalam Kerjasama Pengembangan Kampung Keramat ini dapat dipaparkan bahwasannya berkaitan dengan pemetaan dan sekaligus pembagian tugas dari masing-masing pihak dalam kerjasama tersebut dapat dilihat sebagai berikut (Sulistyowati, 2019):

\section{a. Perusahaan Cat PT. Propan Raya Kota Malang}

Perusahaan ini merupakan salah satu perusahaan cat yang ada di Kampung Keramat. Adapun tugas yang dilakukan oleh perusahaan ini adalah memberikan bantuan dana. Bantuan dana yang diberikan oleh perusahaan cat tersebut berupa bahan cat yang digunakan untuk menggambar gambar mural yang ada di setiap dinding makam. Namun kegiatan menggambar gambar mural yang ada di setiap dinding makam direalisasikan dalam bentuk event festival mural yang diadakan oleh pihak Kelurahan Kasin.

\section{b. Malang Creative Fusion (MCF)}

MCF adalah merupakan sebuah forum yang mewadahi masyarakat kota Malang dalam meningkatkan daya saing industri kreatif yang mereka miliki. Adapun tugas yang dilakukan oleh 
license

MCF ini adalah memberikan pelatihan dalam memasarkan produk-produk yang dimiliki oleh masyarakat Kampung Keramat melalui laman web yang sudah disediakan oleh pihak MCF tersebut.

\section{c. UTERO Malang}

Merupakan sebuah agen yang juga ikut bekerjasama dalam memembangun wisata tematik Kampung Keramat yang ada di Kelurahan Kasin. Secara umum UTERO ini memiliki berbagai keahlian, baik itu keahlian dalam bidang jasa maupun periklanan, ide ataupun konsep. Keahlian tersebut pada dasarnya adalah akan membantu dalam mewujudkan nilai branding yang dimiliki setiap klien yang membutuhkan bantuan mereka. Adapun yang dilakukan agen ini adalah membuat branding yang diwujudkan dalam bentuk Papan penunjuk arah rute menuju Kampung Keramat, papan nama di setiap jalanan makam yang didalamnya terdapat kata-kata mutiara tentang kehidupan dan kematian, dan juga papan denah lokasi spot-spot wisata yang ada di Kampung Keramat tersebut.

\section{d. IAI (Ikatan Arsitektur Indonesia) Malang}

Adalah sebuah agen yang mempunyai keahlian dalam bidang rancang fisik bangunan. Begitupun juga dalam pengembangan Kampung Keramat. Keahlian dari agen IAI Kota Malang ini juga sangat dibutuhkan dalam mengkonsep perencanaan fisik bangunan yang ada di Kampung Keramat. Oleh karena itu dalam pengembangan Kampung Keramat agen ini memiliki tugas dalam memberikan pendampingan khusus terhadap Kampung Keramat berupa upaya membuatkan konsep rancangan fisik pengembangan Kampung Keramat.

\section{e. Kelurahan Kasin}

Pihak kelurahan selaku representatif dari pemerintah mempunyai tanggung jawab dalam mengelola kegiatan pengembangan di Kampung Keramat tersebut. Artinya Kelurahan Kasin ini merupakan sebagai pihak pemerintah yang menjadi leading sector dalam kerjasama pengembangan Kampung Keramat tersebut. oleh karena itu berbagai kegiatan pengembangan Kampung Keramat ini merupakan upaya kelurahan sebagai leading sector sebagai fasilitator dalam mendukung kegiatan kerjasama pengembangan kampung tersebut.

\section{f. Pokdarwis}

Pokdarwis merupakan sebuah kelompok masyarakat yang bergerak sebagai kelompok sadar wisata. Pokdarwis di Kampung Keramat ini dikepalai oleh Pak Azhari, sehingga pada pengambangan Kampung Keramat beliau mempunyai fungsi dalam mengelola Kampung Keramat secara berkelanjutan.

\section{Relasi Antar Pihak Yang Terlibat dalam Kerjasama}

Perlu diketahui bahwasannya Relasi antar pihak yang terlibat dalam kerjasama ini merupakan sebuah hubungan yang dibangun dalam upaya penyelenggaraan proses kerjasama, khususnya dalam kerjasama pengembangan Kampung Keramat di Kelurahan Kasin Kecamatan Klojen Kota Malang. adapun penjelasan lebih rinci dapat dilihat sebagai berikut. 


\section{a. Pengorganisasian}

Berdasarkan wawancara yang disampaikan oleh Pak Azhari Selaku Kepala pokdarwis Kampung Keramat dapat dipaparkan bahwasannya upaya pendelegasian wewenang yang dilakukan oleh pihak kelurahan kepada pokdarwis adalah berupa pendelegasian dalam upaya pengembangan Kampung Keramat secara berkelanjutan. Bentuk pendelegasiannya adalah pendelegasian tersebut diberikan kepada pokdarwis kemudian pihak pokdarwis menindak lanjutinya dengan cara memberikan tugas kepada setiap Rt yang ada di Kampung Keramat untuk merawat segala aset yang sudah dibangun, menjaga keamanan Kampung Keramat untuk menghindari kejahatan yang tidak diinginkan, dan sampai pada mempromosikan Kampung Keramat ke khalayak umum agar Kampung Keramat dapat dikenal di seluruh kalangan masyarakat. Kemudian selain pengorganisasian dalam bentuk pendelegasian wewenang, pihak kelurahan juga melakukan pengorganisasian dalam upaya mengumpulkan berbagai pihak yang terlibat dalam kerjasama pengembangan Kampung Keramat agar dapat hadir dalam forum musyawarah. hal ini bertujuan agar pihak kelurahan dapat mewadahi segala ide-ide ataupun usulan-usulan dari pihak-pihak yang terlibat dalam forum tersebut demi keberlanjutan pengembangan Kampung Keramat.(Azhari,2019).

\section{b. Dialog Tatap Muka Melalui Musyawarah}

Perlu kita ketahui bahwasannya musyawarah dalam upaya pengembangan Kampung Keramat secara berkelanjutan pihak kelurahan sebagai leading sector dalam kerjsama ini telah mengupayakan untuk mengumpulkan berbagai pihak dalam forum musyawarah. forum musyawarah yang dilaksanakan ini sangat beragam. Forum musyawarah ini terdapat 4 macam yang sudah dilaksanakan di Kampung Keramat tersebut diantaranya adalah: 1) Forum Musyawarah perencanaan pengembangan Kampung Keramat. forum ini merupakan forum yang bertujuan untuk menampung segala ide-ide yang dimiliki oleh masyarakat, sehingga setelah ide-ide tersebut tertampung kemudian diwujudkan dalam sebuah proposal yang akan dilombakan pada event lomba kampung tematik di kota Malang. 2) Musyawarah pembuatan branding, forum ini dibentuk dengan tujuan untuk membuat papan nama bertuliskan papan mutiara dan papan denah lokasi Kampung Keramat. adapun mitra dari kegiatan ini adalah UTERO Malang. 3) Forum musyawarah pelatihan memasarkan produk. Forum ini dibentuk dengan tujuan untuk merencanakan pemberian pelatihan kepada warga Kelurahan Kasin agar mereka bisa memasarkan produknya melalui web yang sudah disediakan. Sehingga pemasaran mereka lebih efektif. Adapun mitra dari kegiatan ini adalah MCF (Malang Creative Fusion) Malang. 4) Forum musyawarah pengecatan gambar mural. Forum ini bertujuan untuk merencanakan pengecatan gambar Mural di dinding makam umum Kasin dan rumah warga agar terlihat indah. Mitra dari kegiatan ini adalah PT. Propan Malang.

\section{c. Program Kegiatan Pengembangan Kampung Keramat}

Berdasarkan wawancara dengan Bu Lurah Kelurahan Kasin selaku leading sector dalam kerjasama ini dapat dipaparkan bahwasannya dalam rangka upaya pengembangan Kampung Keramat secara berkelanjutan maka sangat diperlukan adanya program kegiatan. Program kegiatan ini dilaksanakan sebagai dasar pengembangan Kampung Keramat sebagai kampung wisata. Oleh karena itu dalam hal ini terdapat dua program kegiatan yang akan dilaksanakan yakni program 
license

pembangunan fisik dan non fisik.(Lurah Kasin,2019)Berkaitan dengan program pembangunan fisik, rencananya akan dilaksanakan di RT. 07,08, dan 09. Adapun pembangunan fisik terdapat 9 macam spot, diantaranya spot parkir, spot gapura makam, spot sentra UKM, spot taman, spot museum kehidupan, spot sungai, spot kreatif, spot seribu tangga, dan spot selfie dan rumah singgah. Namun pembangunan fisik tidak hanya ini yang direncanakan. Mereka juga melakukan kegiatan pembuatan branding papan nama dan papan denah lokasi Kampung Keramat, dan Pengecatan gambar mural untuk menambah keindahan di Kampung Keramat. kemudian selanjutnya berkaitan dengan pembangunan non fisik yang dilakukan adalah dengan memberikan pelatihan cara memasarkan produk melalui web sehingga pemasaran produk warga Kampung Keramat efektif dan efisien.

\section{d. Pra Pelaksanaan Program Kegiatan Pembangunan Fisik dan Non Fisik}

Berdasarkan wawancara dengan Pak Afis, selaku pihak pendamping Kampung Keramat dari IAI (Ikatan Arsitektur Indonesia) Malang dapat dipaparkan bahwasannya sebelum dilaksanakannya program kegiatan pembangunan fisik dan non fisik tersebut ada beberapa hal yang perlu dilakukan terlebih dahulu, yakni yang pertama adalah melakukan survey dan analisa di lapangan kegiatan survei ini dilakukan untuk menganalisis pokok permasalahan yang ada di lapangan. sehingga nantinya permasalahan tersebut dapat dijadikan sebagai sebuah potensi dalam pengemangan Kampung Keramat. yang kedua adalah Musyawarah perencanaan program pembangunan Kampung Keramat. forum ini dilakukan setelah melalui tahap survey dan analisa bersama di lapangan dengan berbagai pihak yang terlibat, dan setelah survey dan analisa di lapangan tersebut selesai barulah proses musyawarah tersebut dilaksanakan. dalam musyawarah ini merupakan tahap untuk menampung segala ide-ide masyarakat tentang Kampung Keramat. sehingga setelah ide-ide tersebut ditampung kemudian direalisasikan dalam sebuah bentuk rancangan fisik penegmbangan Kampung Keramat. yang ketiga adalah pembuatan proposal. Tahap ini merupakan tahap terakhir yang dilakukan setelah ide-ide masyarakat tersebut tertampung melalui forum musyawarah perencanaan pengembangan Kampung Keramat. sehingga ide-ide tersebut kemudian dituangkan dalam sebuah proposal yang akan dilombakan pada saat event lomba kampung tematik di kota Malang pada tahun 2017.

\section{Pelaksanaan Program Kegiatan Pembangunan Fisik dan Non Fisik}

Berdasarkan wawancara dengan Ibu Yuyun Sulistyowati selaku Lurah dari Kelurahan Kasin selaku leading sector dalam kerjasama ini dapat dipaparkan bahwasanya beberapa pembangunan fisik dan non fisik yang sudah terlaksana dan sudah dibangun di Kampung Keramat saat ini masih difokuskan di wilayah RT. 07. Adapun pembangunan yang sudah dilaksanakan bisa dilihat sebagai berikut (Lurah Kasin, 2019):

\section{a. Pembangunan Jalan di Seputaran Kampung Keramat}

Perlu diketahui bahwasanya pembangunan jalan tersebut merupakan pembangunan yang sangat vital, karena pembangunan jalan tersebut akan mempermudah akses para wisatawan dalam berkunjung ke tempat wisata. Pembangunan jalan ini direalisasikan dalam bentuk pembangunan pavingisasi jalan yang ada setiap lintas jalan Kampung Keramat, tepatnya dibangun di wilayah RT. 
license

07. Sehingga saat ini akses jalan tersebut sudah dapat dinikmati para pengunjung yang datang area pemakaman umum untuk kegiatan ziarah wisata religi.

\section{b. Museum Kehidupan Kampung Keramat}

Proyek Museum Kehidupan merupakan salah satu pembangunan yang sudah terlaksana yang tepatnya berada di wilayah RT. 07. Museum kehidupan ini adalah sebuah museum yang mana didalamnya terdapat beberapa biografi mengenai Habib Abdul Qadir bin Faqih yang makamnya berada di wilayah pemakaman umum Kasin tersebut. selain terdapat biografi habib juga terdapat beberapa tulisan atau buku tentang proses kehidupan manusia dari lahir sampai dengan kematian agar memberikan pemahaman kepada para pengunjung tentang kehidupan setelah mati.

\section{c. Spot Taman}

Area ini merupakan salah satu area yang pembangunanya sudah terlaksana dan saat ini taman tersebut sudah bisa dinikmati oleh warga di sekitaran Kampung Keramat. Letak area ini tepatnya di RT. 07 Gang Keramat yang berdekatan secara langsung dengan wilayah pemakaman umum kasin. Sebagaimana yang terlihat saat ini taman tersebut sudah ada beberapa tanaman hias, hiasan ban, bebatuan, lampu penerang dan sampai pada tulisan Kampung Keramat tersebut sudah tertata dengan rapi dan terlihat begitu indah.

\section{d. Gapura Makam}

Pembangunan gapura makam ini merupakan salah satu pembangunan yang penting karena gapura makam ini adalah salah satu gerbang pintu masuk ke wilayah wisata Kampung Keramat. pembangunan gapura ini sudah terlaksana tepatnya di wilayah RT. 07. berdasarkan yang terlihat saat ini gapura makam sudah diberikan hiasan nisan yang dipasang di atas gapura sesuai dengan karakter Kampung Keramat yang berada di wilayah pemakaman umum Kasin.

\section{e. Pembangunan Sentra UKM}

Pembangunan sentra UKM ini merupakan pembangunan yang disediakan khusus bagi warga Kampung Keramat yang ingin berjualan. Sentra UKM ini dibangun di wilayah RT. 07 tepatnya berada di depan Makam Umum Kasin. Pembangunan ini sudah berhasil dilaksanakan namun sayangnya stand tersebut masih sepi dan masih relatif sedikit bagi yang menggunakan stand tersebut.

\section{f. Pembangunan Pergola}

Pembangunan pergola di Kampung Keramat ini merupakan pembangunan yang dilakukan dalam rangka untuk menambah keindahan. Sehingga pembangunan ini hanya bersifat sebagai fasilitas tambahan. Pembangunan ini sudah terlaksana di RT. 07, sehingga Pergola ini selain berfungsi sebagai hiasan juga berfungsi sebagai berfungsi sebagai penghubung antara makam di wilayah sebelah timur dan sebelah baratnya.

\section{g. Pembuatan Branding}

Pembuatan branding ini merupakan salah satu hal penting dalam memberikan identitas Kampung Keramat, karena dengan adanya branding citra Kampung Keramat di mata pengunjung akan lebih popular. adapun mitra kegiatan ini adalah UTERO Malang. Branding ini sudah terpasang di wilayah RT. 07 dengan dua macam tipe yakni branding papan nama bertuliskan kata-kata mutiara dan papan denah lokasi Kampung Keramat. Sehingga dalam hal ini pembuatan branding sudah sukses dilaksanakan. 
license

\section{h. Pengecatan Gambar Mural}

Pengecatan gambar mural ini sejatinya adalah untuk menambah keindahan di wilayah Kampung Keramat. Adapun mitra kegiatan ini adalah Perusahaan cat PT. Propan Malang. Berdasarkan kondisi saat ini pengecatan gambar mural ini sudah dilaksanakan di setiap dinding makam umum Kasin dan rumah warga, tepatnya berada di wilayah RT. 07. Sehingga gambar tersebut saat ini sudah dapat dinikmati oleh warga sekitar.

\section{i. Pelatihan pemasaran Produk}

Pelatihan pemasaran produk ini merupakan salah satu agenda pembangunan non fisik di Kampung Keramat. Adapun mitra dalam kerjasama ini adalah MCF (Malang Creative Fusion). Sehingga dalam kegiatan ini warga Kampung Keramat dilatih untuk memasarkan produk yang mereka miliki dengan melalui laman web yang sudah disediakan pihak MCF. Sehingga harapannya pemasaran produk tersebut lebih efektif dan efisien.

\section{Sumber Pembiayaan Pengembangan Kampung Keramat}

Berdasarkan wawancara dengan Ibu Yuyun Sulistyowati selaku leading sector dalam kerjasama ini dapat dipaparkan bahwasannya sumber pembiayaan Kampung Keramat dapat diasumsikan menjadi 2 macam. Pembiayaan pertama adalah sumber pembiayaan disaat sebelum lomba. Pembiayaan disaat sebelum lomba ini merupakan pembiayaan yang bersumber murni dari dana swadaya masyarakat dan dana bantuan dari kelurahan. Pada saat sebelum lomba tersebut sumber pembiayaan ini diperuntukkan untuk kebutuhan konsumsi bagi para peserta lomba dan biaya upah jasa bagi para peserta lomba. Kemudian yang kedua adalah pembiayaan pasca lomba. Pembiayaan pasca lomba ini merupakan pembiayaan yang mengarah pada pembiayaan program pembangunan fisik yang ada di Kampung Keramat. adapun pembiayaan yang didapatkan tersebut berasal dari menang lomba yang mana dana tersebut juga bersumber dari dana APBD Kota Malang (Sulistyowati, 2019).

\section{Monitoring dan Evaluasi Hasil Temuan Saat Kerjasama}

Perlu diketahui bahwasanya monev ini merupakan sebagai salah satu cara untuk mengetahui seberapa jauh kegiatan kerjasama pengembangan Kampung Keramat yang sudah dapat dijalankan saat ini, apakah berjalan sesuai dengan perencanaan yang sudah disepakati bersama atau malah sebaliknya. Berdasarkan wawancara dengan Lurah Kelurahan Kasin selaku leading sector dalam kerjasama ini dapat dipaparkan bahwa temuan hasil monev tersebut dapat dilihat pada tabel berikut: 
Tabel 4.1 Hasil Monev Pengembangan Kampung Keramat Tabun 2017

\begin{tabular}{|c|c|c|c|c|c|}
\hline No & $\begin{array}{c}\text { Tahun } \\
\text { Pelaksana } \\
\text { an }\end{array}$ & $\begin{array}{l}\text { Rencana } \\
\text { Kegiatan }\end{array}$ & $\begin{array}{c}\text { Penanggung } \\
\text { Jawab }\end{array}$ & $\begin{array}{c}\text { Realisasi/Capaian } \\
\text { Kegiatan }\end{array}$ & Analisis \\
\hline 1 & 2017 & Paving & CV Madrika & $\begin{array}{l}\text { Pembangunan } \\
\text { paving masih } \\
\text { terealisasi di RT. } \\
07\end{array}$ & \multirow{8}{*}{$\begin{array}{l}\text { Secara teknis } \\
\text { tidak ada } \\
\text { kendala dan } \\
\text { secara kinerja } \\
\text { seluruhnya } \\
\text { berjalan } \\
\text { dengan baik } \\
\text { karena pihak } \\
\text { CV Madrika } \\
\text { sudah } \\
\text { melaksanakan } \\
\text { progress } \\
\text { pembangunan } \\
\text { fisik maupun } \\
\text { non fisik sesuai } \\
\text { yang } \\
\text { direncanakan. } \\
\text { Adapun } \\
\text { Pengawasan } \\
\text { dari } \\
\text { pemerintah } \\
\text { melalui } \\
\text { DISPERKIM } \\
\text { sudah } \\
\text { dilakukan } \\
\text { secara intens, } \\
\text { sehingga }\end{array}$} \\
\hline 2 & 2017 & $\begin{array}{l}\text { Museum } \\
\text { Kehidupan }\end{array}$ & CV Madrika & $\begin{array}{l}100 \% \text { Terealisasi } \\
\text { di RT. 07. bahkan } \\
\text { didalamnya sudah } \\
\text { tersedia rak buku, } \\
\text { sofa, TV LED } \\
\text { dan Miniatur } \\
\text { Denah Lokasi } \\
\text { Kampung } \\
\text { Keramat }\end{array}$ & \\
\hline 3 & 2017 & Taman & CV Madrika & $\begin{array}{l}100 \% \text { Terealisasi } \\
\text { di RT. 07. sudah } \\
\text { ada hiasan bunga, } \\
\text { rumput dan } \\
\text { hiasan ban. }\end{array}$ & \\
\hline 4 & 2017 & Sentra UKM & CV Madrika & $\begin{array}{l}100 \% \text { Terealisasi } \\
\text { di RT. } 07 .\end{array}$ & \\
\hline 5 & 2017 & Area Parkir & CV Madrika & $\begin{array}{l}100 \% \text { Terealisasi } \\
\text { di RT. } 07 .\end{array}$ & \\
\hline 6 & 2017 & $\begin{array}{l}\text { Pembangunan } \\
\text { Pergola }\end{array}$ & CV Madrika & $\begin{array}{l}100 \% \text { Terealisasi } \\
\text { di RT. 07.sudah } \\
\text { ada hiasan ban di } \\
\text { pergola tersebut. }\end{array}$ & \\
\hline 7 & 2017 & $\begin{array}{l}\text { Pengecatan } \\
\text { Gambar Mural }\end{array}$ & $\begin{array}{l}\text { PT. } \\
\text { PROPAN } \\
\text { MALANG }\end{array}$ & $\begin{array}{l}100 \% \text { Terealisasi } \\
\text { di RT. } 07\end{array}$ & \\
\hline 8 & 2018 & $\begin{array}{l}\text { Pembuatan } \\
\text { Branding }\end{array}$ & $\begin{array}{l}\text { UTERO } \\
\text { MALANG }\end{array}$ & $\begin{array}{l}100 \% \text { Terealisasi } \\
\text { di RT. } 07\end{array}$ & \\
\hline
\end{tabular}




\begin{tabular}{|l|l|l|l|l|l|}
\hline 9 & 2018 & Pelatihan & MCF & $100 \%$ Terealisasi & pembangunan \\
& & Promosi Produk & Merjalan \\
& & Melalui Web & & & $\begin{array}{l}\text { di RT. 07 } \\
\text { dengan lancar } \\
\text { sesuai dengan } \\
\text { yang } \\
\text { diharapkan. }\end{array}$ \\
& & & & & \\
\hline
\end{tabular}

Sumber : Diolah Oleh Peneliti Tahun 2019

Berdasarkan tabel tersebut dapat dijelaskan bahwasanya dari berbagai kegiatan baik yang berkaitan dengan pembangunan fisik maupun non fisik secara keseluruhan dapat dikatakan berhasil, karena pembangunan yang ada sudah 100\% terlaksana dengan baik sesuai dengan sudah direncanakan. Jika dilihat secara teknis dalam pembangunan Kampung Keramat tidak ditemukan kendala yang menghambat. Sedangkan jika dilihat dari sisi kinerja para pihak, khususnya CV Madrika sebagai pihak yang bertanggung jawab dalam pembangunan fisik, juga sudah melakukan pengawasan secara intensif pada saat proses pembangunan. Adapun Pengawasan dari pemerintah melalui DISPERKIM juga sudah dilakukan secara intens, sehingga pembangunan fisik dan non fisik secara keseluruhan berjalan dengan lancar sesuai dengan yang diharapkan.

\section{Pelaporan}

Perlu kita ketahui bahwa pelaporan secara definisi dapat dikatakan sebagai kegiatan yang dilakukan untuk melaporkan hasil pelaksanaan program kegiatan Pembangunan yang telah dicapai oleh bawahan kepada atasannya. Begitupun juga dengan pengembangan Kampung Keramat. Berdasarkan wawancara yang disampaikan oleh Pak Azhari Selaku Kepala Pokdarwis Kampung Keramat dapat dipaparkan bahwasannya Kampung Keramat memiliki dua program, yakni program pembangunan fisik diantaranya spot parkir, spot gapura makam, spot sentra UKM, spot taman, spot museum kehidupan, spot sungai, spot kreatif, spot seribu tangga, dan spot selfie dan rumah singgah. Kemudian program pembangunan non fisik yaitu terdapat upaya pelatihan cara memasarkan produk Kampung Keramat melalui laman web.

Kemudian selanjutnya pihak-pihak yang terlibat diantaranya adalah IAI (Ikatan Arsitektur Indonesia) sebagai pihak pendamping Kampung Keramat dalam menentukan desain rancangan fisiknya, MCF (Malang Creative Fusion) Sebagai pihak yang memberikan pelatihan memasarkan produk melalui web, UTERO Malang sebagai pihak yang membuatkan branding papan nama bertuliskan kata-kata mutiara dan papan denah lokasi Kampung Keramat, Kelurahan Kasin sebagai leading sector dalam kerjasama pengembangan Kampung Keramat, dan Pokdarwis sebagai kelompok masyarakat sadar wisata yang bertugas dalam mengelola Kampung Keramat secara berkelanjutan.

Kemudian berkaitan dengan sumber pembiayaan dapat diasumsikan menjadi dua macam yaitu pertama Pembiayaan disaat sebelum lomba ini merupakan pembiayaan yang bersumber murni dari dana swadaya masyarakat dan dana bantuan dari kelurahan yang diperuntukkan untuk kebutuhan konsumsi bagi para peserta lomba dan biaya upah jasa bagi para peserta lomba. Poin kedua adalah sumber sumber pembiayaan pasca lomba yang mana sumber pembiayaan Kampung 
license

Keramat berasal ini dari dana hadiah Lomba Juara 3 Kampung Tematik Se-Malang Raya tahun 2017 yang mana dana ini sebenarnya bersumber dari Dana APBD Kota Malang Tahun 2017 dan kemudian dana ini diperuntukkan untuk pengembangan Kampung Keramat.

Selanjutnya berkaitan dengan pelaksanaan pengembangan Kampung Keramat dapat disampaikan terdapat beberapa pembangunan yang sudah dibangun. Pembangunan ini terealisasi di RT. 07. pembangunan fisik yang bisa dilihat saat ini diantaranya adalah Pembangunan Jalan di Seputaran Kampung Keramat, spot parkir, spot taman, stand sentra UKM, pergola, museum kehidupan, pembuatan Branding papan nama dan papan denah lokasi Kampung Keramat dan pengecatan gambar Mural. Sedangkan pembangunan non fisik yang sudah terlaksana yaitu pelatihan memasarkan produk melalui web. Kemudian yang terakhir adalah berkaitan dengan hasil Monev. Berdasarkan hasil monev yang sudah dilaksanakan di Kampung Keramat secara teknis maupun berkaitan dengan kinerja secara keseluruhan tidak ditemukan kendala. Bahkan pembangunan di RT. 07 secara keseluruhan sudah terealisasi 100\%. Bahkan pengawasan dari pihak CV. Madrika dan DISPERKIM sudah intens dilakukan.

\section{Kesimpulan}

Berdasarkan pemaparan panjang yang sudah dibahas oleh penulis diatas dapat disimpulkan bahwa bahwa awal mula terbentuknya kerjasama pengembangan Kampung Keramat sebenarnya berawal dari adanya lomba kampung tematik se-Malang Raya yang diadakan oleh pemerintah kota Malang melalui Barenlitbang pada tahun 2017. Kebetulan Kampung Keramat mendapatkan juara 3 sehingga Kampung Keramat mendapatkan hadiah menang lomba sebesar 1 miliar yang kemudian dipergunakan untuk pengembangan Kampung Keramat. kemudian berkaitan dengan pelaksanaan pembangunan Kampung Keramat baik fisik maupun non fisik secara keseluruhan sudah terlaksana dengan baik di wilayah RT. 07. kemudian berkaitan dengan hasil Monev baik secara teknis maupun kinerja tidak ditemukan kendala, karena seluruh pihak yang terlibat sudah menjalankan tugas masing-masing dengan baik.

\section{Referensi}

Adibrata, J. A., Sasmitadiharjo, A., \& Rahmarilla, M. D. (2020). Peran Pemuda dalam Sustainable Development Goals Kesebelas: Studi Kasus Kampung Jodipan Malang. Global and Policy Journal of International Relations, 8(02). https://doi.org/10.33005/jgp.v8i02.2416

Hidayatullah, M. I. (2018). Walikota Malang Resmikan Kampung Kramat Sebagai Destinasi Wisata. Propan News. https://news.propanraya.com/news-event/walikota-malang-resmikankampung-kramat-sebagai-destinasi-wisata

Milles, M. B., \& Huberman, M. A. (1992). Analisis Data Kualitatif Buku Sumber Tentang Metode-Metode Baru. UI Press.

Primavera, A. (2017). Warga Kasin Sulap Makam Jadi Kampoeng Kramat. Ngalam.Co. https://ngalam.co/2017/02/26/warga-kasin-sulap-makam-jadi-kampoeng-kramat/

Sakti, S. A. C. (2017). Sudah Dapat Juara 3 Lomba Kampung Tematik, Kampung Kramat Kasin di Malang Terus Lakukan Pembangunan. Tribun Jatim. https://jatim.tribunnews.com/2017/11/06/sudah-dapat-juara-3-lomba-kampung-tematik- 
Copyright (C) 2021, Muhammad Fahmil Islami, Khrisno Hadi

This is an open access article under the CC-BY-SA

license

kampung-kramat-kasin-di-malang-terus-lakukan-pembangunan

Silaban, A. A. H., \& Bhaskara, G. I. (2020). Tingkat Partisipasi Masyarakat Lokal Dalam

Pengembangan Kampung Wisata Kreatif Dago Pojok di Kota Bandung. Jurnal Destinasi

Pariwisata, 8(1), 74. https://doi.org/10.24843/jdepar.2020.v08.101.p10

Sugiyono. (2016). Metode Penelitian Kuantitatif dan Kualitatif dan ReD. Alfabeta.

Wanna, J. (2008). Collaborative government: meanings, dimensions, drivers and outcomes. In

Collaborative Governance. ANU Press. https://doi.org/10.22459/CG.12.2008.01

\section{Wawancara}

Sulistiyowati, Yuyun. (2019). Kota Malang, 23 April 2019

Azhari. Abdullah (2019). Kota Malang, 12 Mei 2019

Abdillah, Afis.(2019). Kota Malang, 18 Mei 2019
Sospol: Jurnal Sosial Politik Vol 7 No 2 (2021), pp.176-188 